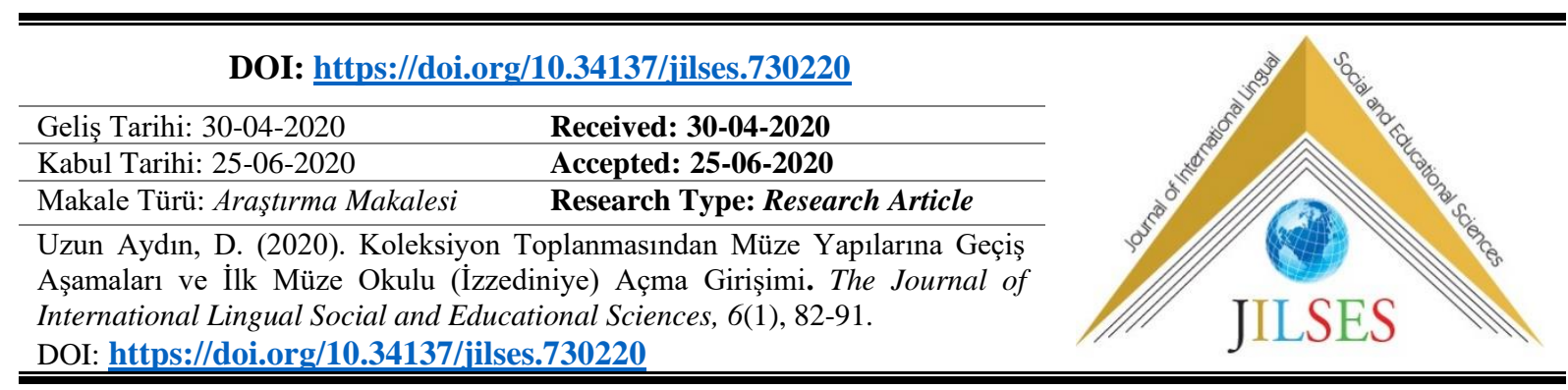

\title{
Koleksiyon Toplanmasından Müze Yapılarına Geçiş Aşamaları ve İlk Müze Okulu (İzzediniye) Açma Girişimi*
}

\author{
Derya UZUN AYDIN ${ }^{1}$
}

$\ddot{O} z$

Insanoğlu, erken tarihlerden itibaren önemli eşyaları toplama ve saklama ihtiyacı içinde olmuştur. Eserlerin toplanması, korunması ve halka sunulması koleksiyonculuk anlayışından müze anlayışına giden yolu açmıştır. Neticede müzelerde yer alan hazineler de, aslında koleksiyonların ilk örnekleridir. Tarihte ortaçağ döneminde, kiliseler birer "koleksiyoncu" iken yerini sonradan soylulara bırakmıştır. Asıl "müze koleksiyonu” kavramı da Rönesans evresiyle önem kazanmıştır. 19.yüzyılda daha da önem kazanan ve bir çeşit "koleksiyon evi" olarak görebileceğimiz müzeler, Osmanlı topraklarında da ayn ihtiyaçlardan doğmuştur. Bu yüzyıllarda doğan Osmanlı müzeciliği, Osmanlı hükümeti tarafindan "Müze-i Hümayun” adıyla anılmıştır. Osmanlı müzeciliğine geçiş aşamaları da;artan ve çoğalan hazineleri toplama ve saklama gereksinimini karşılamaya yönelik olmuştur. Sıra; bu müzelere ya da koleksiyon evlerine gerekli olacakdonanıml elemanlar yetiştirmeye gelmiştir. Neticede, 1875 'te Osmanlı padişah tarafindan onaylanan bir tezkere ile "müzecilik ve eski eserler alanında uzman yetiştirmek" amacılla bir müze okulu yani "Müzeyi Hümayun Mektebi-İzzediniye" açılması planlanmıştır. Böylelikle kazı yapabilecek, eser toplayabilecek ve bunları koruyabilecek kişiler (bir çeşit koleksiyoncu) yetişmiş olacaktır. Ancak bu okul, tüm çabalara rağmen eğitime başlayamamış ve sonrasında da yerini "Sanayi-i Nefise Mektebi"ne bırakmıştır.

Anahtar Kelimeler: Koleksiyon, Toplama, Müze, Müze-i Hümayun Mektebi, İzzediniye.

\section{Transition Processes From Gathering Collection to Museum Buildıng and First Initiative of Establishing Museum School (İzzediniye)}

\begin{abstract}
Among the basic companents which are pioneering the advancement of archeolog science, people's collection curisioty from past to present and the importance of the concepts such as developing collections are quite big. In the process of time, collections were showed to public and these collections were opened to public. In this way, the concepts of the museum museology were born. The first steps were taken for the museums with the collection of the collections. "Museums" are the institutions where cultural properties were collected and exhibited. Museums are places that are communed with the city and they reflect the things that belong to the city. The goal of archeology is to resurrect, but the goal of the museum is to give new life. It is probable to say about protomuseological concept in Ottoman. This concept coverrs the spoils of war or gathering equipments The arcitectural pieces, sculpteres and reliefs belonging to the old period were settle down on Alaaddin hill fortification walls of Konya. Thus, exposure and collection or promuseology were made. In the period of the third Ahmed, "Cebehane-i Amire" was restored and its name was turned into "Darü'l Esliha". In this place, now, precious items are also showed/displayed. So, according to some people, "Darü'l Esliha" is also Pioneer of formal museums. In time, Aya Irini took over this task of hiding. In 1869, Works of art collected in Aya Irini were opened to visit with the name of "Muze-i Humayun".

After some time, because of expectations, the personnels who understand archeology and old artifacts were needed. In this context, it was decided to establis school named as "Izzediniye-Asar-l Atika school-Muse-i Humayun school" or archeology school attached to "Muze-i Humayun".
\end{abstract}

Key words: Collection, Gathering, Museum, Müze-i Hümayun Mektebi,İzzediniye.

\footnotetext{
* Bu çalışma, 11-15 Mart 2015 tarihinde düzenlenen Ankara Dil Tarih ve Coğrafya Fakültesi, 7. Uluslararası Genç Sanat Tarihçiler Sempozyumunda sunulan sözlü bildirinin genişletilmiş versiyonudur.

${ }^{1}$ Dr. Öğr. Üyesi, Batman Üniversitesi, derya.uzunaydin@batman.edu.tr, http://orcid.org/0000-0001-8063-2144
} 


\section{Giriş ve Yöntem}

İnsanların gelişim ve değişimlere açık varlıklar oldukları bilinmekle birlikte, kendilerini ya da değer verdiklerini unutturmama çabaları da oldukça önemlidir. İlk etapta ihtiyaçlarını gidermek zorunda olan insanoğlu, bununla birlikte kimi zaman dinsel güdülerini doyurmak gayesiyle de araştırmış, keşfetmiş ve toplayıcılığa başlamıştır (Türkseven, 2010, s.1).

İşte bu toplama ve keşfetme arzusu gitgide gelişen insanoğlunun bu serüveni, onları müzecilik ve müze kavramlarına kadar götürmüş ve günümüz sanat koleksiyonerciliğine de vasıl olmuştur. Buradan yola çıkarak sanat eserlerinin, müzelerin ve arkeolojinin önemi anlaşılarak ilk müze okulu olan "İzzediniye" araştırmamıza girmiş olur. Araştırılan kaynaklar veya web bağlantıları çalışmamamızın oluşmasında bizlere yöntem olarak yardımcı unsurları oluşturmuşlardır.

\section{Koleksiyon ve Müzecilik Üzerine}

Latince "colligere" fiilinden türemiş ve sözcük anlamı öğrenmek, zevk almak veya yarar sağlamak amaciyla bir araya getirilmiş ve sınıflandırılmış nesneler bütünü olarak bilinen "koleksiyon" terimi; sanat yapıtlarını merak, ilgi veya ihtiyaçtan dolayı toplama işi olarak da tanımlanabilmektedir. Zamanla koleksiyonların halka gösterilmesi ve kamuya açık hale gelmesiyle de "müze ve müzecilik” kavramları doğmuştur (Yaraş,1994, s.19-21 ; Dede, 2012, s.12).

Müze terimi de“mousaion”dan türemiş olup; "Mousa'ların (Musa'ların)” veya "Müz'lerin yani esin perilerinin evi” olarak bilinmektedir(Shaw, 2004, s.8; Yücel, 1999, s.18).

Müze kelimesi “museum” olarak, başta Latince olmak üzere diğer dillere geçerken İngilizce'deve Almanca'da aynı şekliyle kalmış, Fransızca'ya "musee” olarak geçmiştir (Gerçek, 1999, s.1). Koleksiyonların toplanılmasıyla ilk adımlarının atıldığından bahsettiğimiz "müzeler”, kültür varlıklarının toplandıkları, sergilendiği kuruluşlardır. Eski eserlerin korunması ve değerlendirilmesiyle birlikte gelecek kuşaklara aktarılması ise, en önemli görevleri arasındadır(Şahin, s.101-125). Koruma ve sergileme gibi amaçları dişında; kültürel alanlarda çalışmalar yapmak amaciyla da kurulmuş olan müzeler, zamanla sosyal aktivitelere de yer vererek:'sanat, tarih, etnografya, bilim, teknoloji, basın, askeri, deniz, bölge ve açık hava müzeleri' gibi çeşitlere ayrılmıştır(Dede, 2012, s.12). Böylelikle müzeler, kentle, kentli ile iç içe olan ve kenti-kentliye ait olan şeyleri yansıtan mekanlar kavramını da kapsar hale gelir. Kent müzeleri kentin geçmişi, coğrafyası, tarihi ve tüm sosyal olguları içererek kenti ve kentliyi temsil ederler (Köse, 2010, s. 3, 7, 9).

Türkiye'nin de 1956'da üyesi olduğu “International Counsil of Museums- (ICOM)" isimli kuruluşa göre müzenin genel tanımı; tarihi, arkeolojik eserlerin ve tabiattan toplanmış nesnelerin teşhir edildiği mekanlar, tabii parklar, nebatat ve hayvan bahçeleri, akvaryumlar ve halkın ziyaretine açık biçimde düzenlenmiş tarihi ören yerleridir(Kuruloğlu, 2010, s. 45-61).

Arkeolojinin amacı diriltmek ise, müzelerinki yeni hayat vermektir (Shaw, 2011, s. 423-441).

Koleksiyonculuğun tarihini paleolitik çağlara- özellikle de mezar yapılarına (MÖ.100 bin ila 40 bin arası)-kadar indirenler olduğu gibi, insanların yerleşik düzene geçtiği tarihleri kabul etmek daha mümkün gözükmektedir. Toplayıcılıkla kendi ihtiyaçlarını gidermek için yiyecek veya giyim eşyası biriktiren insanoğlu, ayrıca savunma amaçlı eşyalar da toplamış ve biriktirmiş zamanla bu birikime değerli olan mücevher ve eşyalar da katılmıştır. Koleksiyon toplamayı; toplum yararına kent yönetimleri tarafından yapılan toplayıcılık (özellikle ruhban sınıfı tarafından) ve belli bir kesim tarafından kişilerce satın alma ya da ganimet toplama yoluyla yapılan koleksiyonculuk olarak ikiye ayırmak da mümkündür. Yerleşik hayata geçen insanoğlunun birikimleri (koleksiyonları) belki de günümüzün en ilkel ilk müze örneklerini oluşturmuşlardır (Türkseven, 2010, s.1 ; Yaraş, 1994, s.19-21).

Mısır ve Mezopotamya uygarlıklarında da, değerli eşyalar yine mezarlarda, mabetlerde ve saraylarda sergilenmiştir. Başta dinsel amaç taşıyan bu sergilemeler ayrıca savaş ganimetleri olarak da hızla çoğalmıştır. Bir güç göstergesi olarak da antik çağda çeşitli eserlerin "thesauroi" denilen hazine dairelerinde korunduğu belirtilmektedir(Yücel, 1999, s.19).Kimileri, gerçek anlamıyla sanatsal değeri olan eserlerin toplanması olayında tarihleri, Greklere kadar indirmek gerekliliğinden söz eder. Nitekim Greklerin "theasuri” dedikleri hazine binaları inşa ettirdiklerinden bahsedilmektedir (Keleş, s.1-17 (e-dergi.atauni.edu.tr/ataunisosbil/article/view/102000000: Erişim 01-01-2015). Kimisi, bu hazine dairelerine "tesauros" demektedir. (Örnek olarak Efes, Delfi verilebilir).Eski Yunanlıların olimpiyat oyunlarında, tanrılarına adadıkları çeşitli hediyeleri de bir birikim oluşturmuştur. Yunanistan'da Atina akropolünde “pinakotek” denilen bir sergi salonu yapıldı ğı dahi bilinmektedir. Klasik çağda oluşan aristokrat sınıfı sayesinde, güzel sanatlara da ilgi artmıştır. Boş zamanları sosyal etkinliklerle doldurma isteği de "müzecilik" ihtiyacını doğurmuştur. Esin perisi adına oluşturulan bu yapılar, birer sanat evidir. 
Bunlar, bir sunaktan ve etrafi çevrili bir alandan oluşmuştur. Buralarda, sıklıkla entelektüel kişiler buluşup, konuşmalar yapılırken, bir yandan da pek çok eser sergilenmiştir. Platon'un MÖ.385'de Atina'da kurduğu "Academia", bir süre sonra "Mouseion" olarak anılmıştır.Böylelikle müzecilikle birlikte, güzel sanatlar da ilerlemektedir (Yaraş, 1994, s.19-21).

Hellenistik dönemde de, eserlerin toplanması yoğunluk kazanmıştır. (MÖ 300-30). Ayrıca klasik çağın (MÖ.50300) önemli Yunan heykelleri ve kopyaları ilginç koleksiyonlar oluşturmaktadır. Hellen çağının ünlü kralı olan I Ptolemaios (MÖ.304-285) 300’lü yıllarda dönemin kültür merkezi olan İskenderiye’deki sarayında, ilk müze ve kütüphaneyi kurmuştur. "Museion-Musa'lar Mabedi” adı da verilen sarayın bu bölümünde, sanat eserlerinin korunup sergilenmesi önemlidir. Koleksiyonculuğun başlamasında önemli unsurlardan biri de, savaşlarda kazanılan ganimetler olmaktadır. Bunlar da, bir çeşit ilkel müze kabul edilebilir. Özellikle Romalılar, Eski Yunan heykellerini toplayarak sergilemeyi tercih etmişlerdir. Bu bağlamda bir çok mabet dolup taşmıştır. Ayrıca bir çok örnek devlet yapılarında, tiyatrolarda, villalarda ya da saraylarda koleksiyonlar meydana getirilmiştir. (Yücel, 1999, s.1, 19-20) Avrupa'da, Ortaçağ sonrasında gelişen bir özel koleksiyon merakı olduğu bilinmekle birlikte, ilk müze örneği sayılabilecek "nadire kabineleri=cabinet of curiosities" ismine de rastlanılmaktadır. Ancak bu küçük koleksiyonları, koleksiyoner sahibinin sadece yakınları ziyaret edebilmektedir(Shaw, 2004, s.10, 14).

Ortaçağın kilise ve manastırları da, dinsel eşyalarla doldurulmuştur. Bunlar arasında, sikkeler, madalyonlar, değerli taşlar yer almaktadır. Dolayısıyla bu dönemlerde, kilise ve manastırlar, bu işte de gücü ellerinde barındırmışlardır (Yücel, 1999, s.19). Sanat eserlerine ilgi bilindiği üzere, Rönesans dönemi ile artmıştır. Bu dönemlerde ilerideki Avrupa müzelerinin ilk temelleri atılmış olmaktadır.1471 yılında Roma Kapitol Koleksiyonu “Capitolino Müzesi” haline getirilmiştir ve 1506'da Vatikan Köşkü’nde Vatikan heykel koleksiyonu kurulmuştur. Kaynaklara göre 1552-1605 yıllarında yaşamış İtalyan hekim "Ulisse Aldrovandi”, doğanın tüm varlıklarından seçtiği örneklerle bir müze kurma girişiminde bulunan bir isim olarak tarihe geçmektedir (Gerçek, 1999 , s.4 ; Şahin, s.101-125). Yine eserleri halka gösterme ve sergileme çabaları adına "Samuel Van Quichberg" isimli bir bilginin, 1665 'te yazdığı ve ilk kez örnek bir müzenin nasıl kurulabileceği konusunu içeren "Inscription" isimli kitabı da oldukça önemlidir.Halka açık ilk müzenin, 1683'de İngiltere'de kurulduğundan söz edilmektedir (Şahin, s.101-125; Yücel, 1999, s.20-21).Kimilerine göreyse ilk müze; Oxford Üniversitesi'nde 1679-1683'te yapılmış olan “Ashmolean Müzesi” kabul edilmektedir. Bu müzenin, "Halk müzesi” olarak açılması önemlidir.Halkın da gezebileceği müzeler fikrinin; 1746' da Fransız yazar "La Font de Saint Yenne tarafından ortaya atıldığı da iddialar arasındadır. ABD'de ilk halk müzesi olarak, 1773'teki “'Charleston Müzesi” de kabul edilmektedir. İngiliz British Musum” dışında, Fransa' da “Louvre müzesi” ve 1785-Philadelphia'da “AmericanMuseum” ve 1819'da Madrid'te "Prado Müzesi”" ile St. Petersburg (Leningrad-Ermitaj (Hermitage) Müzesi bilinen kimi müze örnekleridir. Tarih müzesi kavramı , 19.yy.'da daha bir önem kazanmıştır. Ve 20.yy.'da modern sanat müzeleri hızla çoğalmıştır. 1926'da Uluslar arası Müzeler Dairesi, 1947'de Uluslar arası Müzeler Konseyi olan ICOMOS kurulmuştur (Gerçek,1999, s.5-10 ; Altunbaş, Özdemir, 2012, s.4).

\section{Osmanlı'da eski eser bilinci ve müzeler}

Osmanlı'da ya da Türklerde eski eser bilinci nasıldı veya nasıl başlamıştır? Avrupa'dan Osmanlı'ya gelen bir çok gezgin veya araştırmacının Türkleri “eski eserlere değer vermeyen bir millet olarak görmesi ve onları barbar, uygarlıktan uzaklar” olarak nitelendirmeleri ne acıdır. Bu anlayışın kırılma noktası, 18.yy. sonu ila 19.yy’da Avrupa'daki oryantalizm dalgası olmuştur(Şahin, s. 101-125).

Osmanlı'da önmüzecilik=protomuseological kavramından söz edilmesi mümkündür. Bu kavramı, savaş ganimetleri veya devşirme malzemeler kapsamaktadır. Bilindiği üzere daha Ayasofya inşa edilirken, eski tapınaklardan bir çok taş getirilmiş ve kilisenin duvarlarında kullanılmıştır. Benzer şekilde, İstanbul Rumelihisarı ile Ankara kalesinin duvarlarında da Hellen dönemine ait parçalar ve heykeller kullanıldığından söz edilmektedir. $\mathrm{Bu}$ durum, Osmanlı topraklarında önemli parçaların değerlendirilmesi ve teşhir edilmesi olarak düşünülürse; koleksiyonculuk ve müze anlayışının başlangıç tarihleri de belirlenebilir (Shaw, 2004, s.20-21, 31-32).

Nitekim, Osmanlı müzecilik tarihini çoğu kişi Anadolu Selçuklu dönemine kadar götürmektedir. Selçuklu’ya ait Konya-Alaaddin Tepesi sur duvarlarına, antik döneme ait mimari parçalar ile heykel ve kabartmalar yerleştirilmiş, böylelikle teşhir ve toplama yani önmüzecilik yapılmıştır. Bu durumda, Anadolu'da19.yy.'a kadar; 1. Eserlerin depoda saklanması, 2. Yeni inşa edilen yapılarda tarihi eserlerin kullanılması olarak korumacılık anlayışından söz edilmesi mümkündür (Nazır, 2010, s.98-113 ; Gerçek, 1999, s. 78; Serbestoğlu, Açık 2013, s.157172).Osmanlı'nın Bursa, Edirne gibi ilk saraylarında hazine daireleri inşa edildiği bilinmektedir. Bu bağlamda Fatih Sultan Mehmet'in hazine dairesi ve zengin kütüphanesi oldukça önemlidir. 2 Bayezit döneminde de, kaynaklarda "Enderun hazinesi" tabirine rastlanmaktadır. Yavuz Sultan Selim'in Suriye ve Misir seferleri ile kutsal emanetlerin ve değerli hazinelerin Osmanlı'ya kazandırıldığı bilinmektedir. 3. Murat döneminde de, kadılara kendi idareleri altındaki değerli eserlerin yabancılara satıldığı haberinin duyulmasıyla bunun yasak 
kılınması, koruma anlayışı adına o dönemler için önemli bir olaydır (Gerçek, 1999, s. 78; Türkseven, 2010, s.6, 9).

3. Ahmet döneminde silahların saklandı̆̆̆ "Cebehane-i Amire" onarılmış ve ismi de "Darü’l Esliha" ya dönüşmüştür. Burada artık değerli eşyalar da teşhir edilmektedir. Bu nedenle, kimilerine göre Darü’l Esliha resmi müzelerin de öncüsüdür. Ancak bu tür yerler, devletin güç göstergeleri olup, halka açık olmamaktadır. Darü'lEsliha'nın ismi, 1839'da "Harbiye Ambarı" olarak değişecektir (Shaw, 2004, s.22-25, 41).1867'de Paris'te “Abras Gallery'de eski eser koleksiyonunu gezen Sultan Abdülaziz de, arkeolojinin ne kadar önemli olduğunu fark etmiştir. Ayrıca, Osmanlı'da müzeciliğin gelişiminde; kaçırılan, yağmalanan bir çok eserin payı büyük olmuştur. 19.yy.'da Ege Denizi-Melos adasında bulunmuş Milo Venüsü, (s.13) Efes kazılarından çıkan bir çok parça, Bodrum Halikarnas Mauseloeum'un kısımları kaçırılırken, Gertrude Bell, Arabistanlı Lawrence ve Schliemann gibi isimler tarih sahnesine çıkmışlardır (Shaw, 2011, s.423-441; Gerçek, 1999, s. 14-15, 28-76 ).

Tarihler 1845 yılını gösterdiğinde, Sultan Abdülmecid'in Yalova seyahatinden söz edilmektedir. Bu gezi esnasında sultan, yerde yazıll bir takım mermerler görmüş ve bunların ne olduğunu merak ederek sormuştur. Orada bulunanlardan birisinin, üzerinde ‘Konstantin' yazılı olduğunu söylediği bu mermerleri sultan değerli bulmuş ve bunların derhal yerden kaldırılmasını emretmiştir, ardından da mermerleri İstanbul'a göndertmiştir. Tophane-i Amire'de yüksek rütbeli asker olan Damat Ahmet Fethi Paşa, bu taşları korumak üzere alarak, onları eskiden beri silah deposu olarak kullanılan Aya İrini'de (Cebehane) saklatmıştır. Burada var olan askeri gereçlerle birlikte, artık arkeolojik eserlerin de yavaş yavaş toplanmasıyla ilk müzeciliğin başladığı da söylenegelmektedir(Gerçek, 1999, s.82).

Fethi Ahmet Paşa, Aya İrini'de 1846'da iki koleksiyon oluşturmakta ve bunlara ülkenin her tarafindan gelen arkeolojik parçalar da eklenmektedir. Aya İrini'de (Harbiye Ambarı) oluşturulan "Mecma-i Esliha-i Atika" ve "Mecma-i Asar-1 Atika" teşhir yerleri olarak da açılacaktır (Eldem, 2011, s. 281-329).

Nitekim 1869 yılında da Aya İrini'de toplanan eserler "Müze-i Hümayun” adıyla ziyarete açılmıştır. Böylelikle Osmanlı'da "müze" tabiri, ilk kez talimatnamede de dile getirilmiş olmaktadır. Bu müzenin ilk müdürü de, Galatasaray Lisesi'nde tarih öğretmenliği yapan E. Goold olmuştur. Müzenin bir kataloğu dahi düzenlenmiştir. (Albert Dumont tarafından).Müzeyi ziyarette 100 para ücret taleb edildiği bilinmektedir. Ancak, bunun sonradan 1871 tarihine ertelendiği söylenilir. Ayrıca müze her gün açık olacak, yalnız çarşambaları kadınlara özel olacaktır. Bu müzenin kapsamı; antik eserlerle sınırlı olmasıyken, niteliği de toplama, biriktirme, koruma ve koleksiyon anlayışına dayalı olmasıdır(Gerçek, 1999, s.82; Yücel, 1999, s. 32 ;Kuruloğlu, 2010, s.45-61.Akçura, 1972, s.3942).

1871 'de anlaşılamayan nedenlerle müze kapatılmış ve Goold'un görevi de sona ermiştir. Görevini de kısa süreliğine, Avusturyalı ressam ve memur Terenzio üstlenmiştir. Ahmet Vefik Paşa'nın sadrazamlığı sonrasında, müze tekrar açılmış ve müdür olarak da PhilippAntonDethier atanmıştır (Nazır, 2010, 98-113. ; Serbestoğlu, Açık , 2013, s.157-172).

P. A. Dethier, 1804?-1881 yılları arasında yaşayan, 1872-1881 arasında müze müdürlüğü yapan Alman eğitimci ve arkeologdur. Kendisi, Berlin Üniversitesi'nde 1823-27 yılları arasında arkeoloji, filoloji, tarih ve sanat tarihi okumuştur(Gerçek, 1999, s.169; Türkseven, 2010, s.47). A. Dethier müzecilik adına önemli işlere imza atmıştır. Özellikle de ükedeki yağmalama işleriyle ilgilenir ki, bunların başında Troya hazineleri gelmektedir. Dethier bu konuyla ilgili olarak Atina’ya kadar gitmiş ve Osmanlı hükümeti adına olayı dava etmiştir. Dava, Yunan hükümetinin para ödemesiyle sona ermiştir. Yine onun döneminde, önemli çalışmalar devam etmiş ve müzenin eser sayısı çoğalmaya başlamıştır. Tabii bu durum, zaten nemden dolayı sıkıntılar çıkaran müzenin artık yetersiz kaldığını ve yeni bir yere ihtiyaç duyulduğunu göstermektedir. Osmanlı'da eski eserlerle ilgili nizamnameler çıkarıldığı bilinmektedir. Bunlardan birisi de Dethier döneminde kabul edilmiştir (1874). Ancak bilindiği üzere, daha öncesinde- 1869 yılında da-bir nizamname yayınlanmıştır (Yücel, 1999, s. 36.. Nazır, 2010, 98-113 ; Eldem, 2011, s.281-329). 1874'te ikinci nizamname; 4 bölüm altında toplanmış ve 30 maddelik olarak hazırlanmıştır. Burada, devlet arazisinde yapılan kazıların ve sonuçta çıkarılan eserlerin üçte ikisinin hükümete kalmasına karar verilirken, kazı sahibinin payının iki misline çıkması kararı alınmaktadır. Ve hatta önceki nizamnameden farklı olarak, eserlerin yurt dışına çıkma yasağının kaldırıldığı görülmektedir. Bu durum yine, eski eserler adına taviz demektir. Nizamnamede yurt dışı için, Maarif Nezareti izni şart koşulmuş ve devlete de satın alma hakkı saklı tutulmuştur (Eldem, 2010, s. 56-58. ; Shaw, 2004, s. 110).

\section{Arkeoloji okuluna doğru: girişimler}

Osmanlı'da, arkeoloji ve eski eserlerden anlayan çok sayıda elemana ihtiyaç vardır. Nitekim, Dethier döneminde eski eser ve müzeden anlayacak kişilerin yetiştirilmesi gerekliliğine karar verilmiştir. Neticede de, Müze-i 
Hümayun’a bağlı “İzeddiniye-Asar-1 Atika Okulu-Müze-i Hümayun Mektebi veya Arkeoloji Mektebi” isimleri verilen okul kurulacaktır. Böylelikle, müzeye personel yetiştirilebilecektir. İlk etapta Maarif Nezareti içerisinde eğitim başlayacak, sonrasında ise çalışmalara müzede devam edilecektir. Okula ilk başta 12 öğrenci alınması kararlaştırılır. Ancak ileride bu sayı artırılabilir. Okula kabul edilecek öğrencilerin, Mekteb-i Sultani'den (lise veya dengi okul) mezun olma zorunluluğu getirilmektedir. Okul kadrosunda da, üç öğretmen ve bir yardımcı bulunacaktır. Okul müdürlüğünü ise Dethier üstlenecektir (Shaw, 2004, s. 114; Eldem, 2010, s.170; Kuruloğlu, 2010, s. 45-61).İki y1l eğitim vermesi planlanan okulun öğrencileri, Fransızca, Eski Yunanca, Latince ve Türkçe dilleri yanı sıra Tarih ve Coğrafyayı da bilmelidir. Ayrıca öğrenciler basit çizimler ve tasvirlerin alçıyla resmini yapıp, fotoğrafını çekmeyi de öğreneceklerdir. Yine derslerde, çeşitli taşları da tanıyacaklardır. Okul müfredatında, Antik Yunan ve Roma geçmişi önemlidir. Mektebin alçı dersleri için, Mekteb-i Sanayi'den mezun olup Paris'e giderek bu yönde eğitim almış olan "İstavri”" görevlendirilmiştir. Okulda öğretmenlere yıllık 48 bin, aylık harcamaları için de 2 bin kuruş maaş verilecektir. Öğrencilere de 200'er kuruş harçlık verilecektir. Okulda, Cuma ve Pazar günleri ders yapılmayacak, diğer günler sabah saat 10'dan akşam 18'e kadar öğrenim verilecektir. Yı1 sonunda öğrenciler, İstanbul'a yakın olan ve kazı yapılacak yerlerde çalışacaklardır. Şayet bir öğrenci kazılarda eser bulursa mükâfatlandırılacaktır. Okulu bitiren öğrenci, sonrasında kazılarda görev alabilecektir; eğitimini yarıda kesen olursa da, tüm yapılan masrafları ödemek durumunda kalacaktır. Okula ücret ödemeden devam etmek isteyen olursa ve bunların sayısı da 20'yi geçmezse onlar da kabul edilecekler ancak onlara ödeme yapılmayacaktır. Fakat bunlar da, okulu bitirince diğerleriyle aynı haklara sahip olacaklar, asıl bir öğrenciye herhangi bir şey olursa da yerine yeteneklilerinden birisi geçebilecektir. Sonuç olarak, şubat ayında padişah emri çıkmış ve okul kuruluşu da Sultan Abdülaziz tarafından onaylanmıştır (Yücel, 1999, s. 41-42;Serbestoğlu, Açık, 2013, s.157-172).

Okul açılmasıyla ilgili Sadaret Makamı’na sunulan tezkere şöyledir;

\section{"Sadaret Tezkeresi}

Osmanlı İmparatorluğu dahilinde çıkacak asar-1 atikanın hafriyatına nezaret etmek ve Maarif Nezareti’nin icra vasıtası makamında bulunmak üzere lise veya muadili okul mezunu 12 öğrenci alınarak bir müze okulu açılması ve bu okula üç öğretmen ile bir muavin tayin edilerek verilecek maaş ve diğer masrafları karşılamak için senelik 90 bin kuruşun tahsisi maarif nezareti tezkeresi ile nizamname takdim kılındı. Bu hususta yüksek emirlerinize göre hareket edilecektir. 25 Zilhicce 1291"

Padişahlık makamının da okul açılışını uygun bulduğu anlaşılmaktadır. Şöyle ki;

\section{"Padişah Emri}

Sadaret tezkeresinde belirtilen hususlar incelenmiş ve münasip görüldüğünde okulun açılması hakkında gereğinin yapılması...26 Zilhicce 1291 (1874)( Kocabaş, s.77-78).

İzzediniye Mektebi Nizamnamesi de şu şekildedir;

Madde 1: İstanbul'da eski eser ve sikkelerle ilgili ilim tahsiline mahsus olacak ve Maarif Nezaretine bağlı bir okul kurulacaktır.

Madde 2: Açılacak okula ilk etapta 12 öğrenci alınacak sonra da sayı artırılabilecektir.

Madde 3: Alınacak öğrencilerin Fransızca, Eski Yunanca ve Latince ile Türkçeyi bilmeleri, genel tarih ile coğrafyaya hakim olmaları gerekmektedir.

Madde 4: Okul ilk etapta Maarif Nezaretinde eğitime başlayacak sonra müze binalarından birinde açılacaktır.

Madde 5: Okul eğitim öğretim süresi 2 yıldır. Öğrencilere eski eser ve sikkelerle ilgili dersler verilecek, ayrıca resim tahsili, tasvirlerin alçıdan örneğini alma, eski eser fotoğrafçılığı ve taşlar hakkında dersler verilecektir. 
Madde 6: Okula 3 öğretmen alınması düşünülür.

Madde 7: Öğretmenlere ilk etapta maaş olarak senelik 48 bin kuruş ve diğer masrafları için de 2 bin kuruş tahsis edilecektir.

Madde 8: Öğrencilere çalışacakları kazılar ve araştırma işleri için maaş verileceğinden, tahsil hayatlarında da ihtiyaçları için ikişer yüz kuruş maaş verilecektir

Madde 9: Okul tatil günleri Cuma ve Pazar olacak, diğer günler ders yapılacaktır; ders saatleri 10 ila 16 arası olacaktır. 16-18 arası da müze de eski eserler incelenecek ve bazı günler de sikkeler için bilgi verilecektir.

Madde 10: Sene sonunda öğrenciler İstanbul'a yakın ve eski eserlerin olduğu yerlere götürülüp, buralarda kazı ve araştırmalarla uygulamaya tabi tutulacaklardır.

Madde 11: Götürülen yerlerde bulunan eserlerin kıymetine göre nakdi mükafat da verilecektir.

Madde 12: Eğitimi bitiren öğrenciler devletçe yapılacak kazılarda yada yabancı kazılarda soruşturma görevlerinde ve Müze-i Hümayun'a ait diğer işlerde görev alacaklardır.

Madde 13: Okulu bitirmeden ayrılan öğrenciden ödenen masraflar geri ödetilir.

Madde 14: Okula parasız devam edecek öğrenci olursa, 20 kişiyi geçmeyecek ancak maaş almayacaklardır.

Madde 15:Bu öğrenciler okul bitiminde, diğer öğrencilerin hakkına sahip olacaklardır.

Madde 16: Okulun esas öğrencilerinden ayrılan olursa, bu parasız okuyanların en yeteneklisi onların yerine geçebilecektir ( Gerçek, 1999, s. 104).

Yapılan tüm yazışmalara rağmen, okul açılamamıştır. Kimine göre programı iyi hazırlanamadığından, kimine göre giriş koşullarının sağlanamamasından ya da öğrenci ve öğretmen bulunulamamasından dolayı, kimine göre de yaşanan 93 harbi nedeniyle bu okul açılamamıştır (Akçura, 1972, s. 39-42. ; Türkseven, 2010, s.48).

Okulun faaliyete geçemediğinden söz edilmektedir. Peki okul eğitime başlayabilseydi ne olurdu? Bu okulla, erken tarihlerde Osmanlı'da müzecilik daha emin ve güvenli bir şekilde gelişir ve ilerlerdi. Yeni müze açılışları hızlanır, eski eserlere sahip çıkma olgusu yayılırdı. Özellikle yabancı kazılar disiplin altında olurdu. Kazılar, arkeolojik çalışmalar, bilimsellik kazanır, kaçakçılık önlenir, en önemlisiyse vasıflı ve donanımlı elemanlar yetişirdi. Aslında bugünün de, arkeoloji ve sanat tarihi bölümlerinin ilk öncüsü açılmış olurdu (Gerçek, 1999, s. 104).

Dethier, müze binasını sığamayacak hale getirince, zaten rutubet alan Aya İrini'den çıkılmış ve 1875 'te Çinili Köşk'e taşınılmıştır. Çinili Köşk’te ve bahçesinde eser barındırmak amacıyla yapılan çalışmalar, 1880 yılına kadar sürmüş ve bina hizmete açılmıştır. Dethier de, yaptığı çalışmalardan ötürü ödüllendirilmiştir (Başgelen, 2006, s.114-121. ; B. Nazır, 2010, s. 98-113).

1881'de Müze-i Hümayun müdürü Anton Dethier ölünce, Maarif Nezareti Berlin Müzesi başkatibi Dr. Millhofer ile bir sözleşme imzalama aşamasında iken, Sadrazam Edhem Paşa'nın oğlu olan Osman Hamdi Bey; 11 Eylül 1881 tarihinde müzenin müdürlüğüne atanmıştır. Ayrıca, Sanayi-i Nefise Mektebi de kurulmuş ve onun da müdürlüğüne getirilmiş olan Osman Hamdi Bey döneminde, müzecilik alanında önemli gelişmelere imza atılmıştır. 1884'te yeni nizamname çıkarıldığı bilinmekte ve yabancılara kazılar konusunda sınırlamalar getirilmektedir (Başgelen, 2010, s.5).

1869 tarihli Asar-1 Atika Nizamnamesi'nde tașınmaz eski eserlerle ilgili hükümlere rastlanmamaktadır. 1874'tekinde ilgili üç madde yer alırken, 1884 nizamnamesinde özellikle 4.madde; şahıs ve cemaatlerin mülklerindeki eski eserleri yıkamayacakları ve devletin bu binaların asıl haliyle devamını sağlamakla yükümlü oldukları belirtilmektedir. 5.madde ise, eski eser binaların tahrip edilemeyeceği, yakınlarında taş ocağı açılamayacağı ya da depo olarak kullanılamayacağı hükümleri de yer almaktadır. En önemlisi de artık, herhangi bir eser yurt dışına kesinlikle çıkarılamayacaktır. Böylece her kazı bizzat Osman Hamdi'nin onayına mecburdur(Çal, s.353-378; Eldem, 2010, s.49).

Osman Hamdi Bey çok yönlü bir kişiliktir. Kendisi ressamlığı dışında, arkeologluğu ile de tanınır. Ayrıca diplomatik yönü de unutulmamalıdır. 1867-Paris Uluslar arası sergisinde Abdülaziz ile tanışması, 1876'daki Viyana sergisinde Osmanlı pavyonunu temsil etmesi önemli olaylar arasındadır. Müzecilikte, tanınmış arkeolog 
S. Reinach'ın birikimlerinden ayrıca yararlanan Osman Hamdi; Anadolu, Mısır, Suriye ve Irak'ta bu dönemde yapılan kazılardan elde edilen eserlerin müze koleksiyonuna dahil edilmesiyle, müzenin zenginleşmesini sağlamıştır. O, Türkiye'de müzeciliğin gelişiminde önemli pay sahibidir. Onun ilk arkeolojik kazısı Nemrut tümülüsüdür. Ardından bir çok mezar lahtini bulduğu "Sayda Kazısı" da onu dünyaca ünlü kılmıştır. Sayda lahitlerinin bulunmasıyla artık yeni bir müzeye daha ihtiyaç duyulmaya başlar. Böylelikle, bugünün İstanbulArkeoloji Müzesi yapımına başlanılır (Eldem, 2011, s.281-329; Özsezgin, 2014, s.20, 36). 1891'de işleve hazır hale gelen müze dolunca, ek binaya ihtiyaç duyulmuş ve 1904'te batı yöne ek bir kanat yapılarak burası da 1907'de açılmıştır. 1968'lerde bir yapı eklemesiyle müze son şeklini almıştır. 1995'te Arkeoloji müzesi bünyesinde bir çocuk müzesinin de açıldı̆̆ bilinmektedir (Başgelen, 2006, s. 114 -121. ; Başgelen, 2010, s. 22-23).

1910’da Osman Hamdi Bey ölünce müdürlüğe kardeşi Halil Edhem Bey geçmektedir. Kendisi kardeşine 1892'den beri müdür yardımcısı olarak yardım etmiştir. $\mathrm{O}$ da, kardeşi gibi bilimsel çalışmalara ağırlık vermiş ve yeni bir katalog hazırlamıştır. İslami para koleksiyonunu düzenlemiş, 1914 savaşına kadar kazılardaki eserleri müzeye kazandırmıştır; bunların bir kısmı depolarda koruma altına alınırken, Yunan işgali sırasında Amerikalıların götürdüğü bir kısım eser, onun sayesinde tekrar yurda geri kazandırılmıştır. Onun döneminde Eski Şark eserleri ayrı binaya taşınmıştır. 1914'te de Türk-İslam Eserleri Müzesi açılmaktadır. Nitekim, 1900'lerde Türkçülük ve milliyetçilik gibi akımlarla Türk kültürü ve sanatları canlandırılmak istenmiştir. 1917'de İstanbul'da "Muhafaza-1 Asar-1 Atika Encümesi” kurularak koruma adına önemli bir adım daha atılmış olmaktadır. Cumhuriyet devri ile birlikte, ileriye yönelik koruma çalışmaları da devam edecektir (Akçura, 1972, s. 39-42; Eldem, 2010, s.187; Yücel, 1999, s.61-63).

Atatürk ile müzecilik ve kazı çalışmaları önem kazanmış ve desteklenmiştir. Onun döneminde "Türk Asar-1 Atika Müdürlüğü” kurulmuştur. Müdürlük, sonrasında Hars Müdürlüğü ismini almaktadır. Ve böylelikle müzelerin denetim ve gelişimi sağlanmış olur. 1922'de Türk müzeciliğinin gelişiminde pay sahibi olan bir genelge yayınlanır. Ayrıca bu dönemlerde, pek çok medresenin müze-depo olarak kullanıldığı bilinmektedir. 1929'da Mevlana Müzesi açılmaktadır. Atatürk her zaman milli kazıları ve müzeleri desteklemiştir. 1931'de Bursa, İzmir ve Adana Müzeleri tarafınca ziyaret edilir. Topkapı Sarayı müzeye dönüştürülüp, bir bölümüyle ziyarete açılır (1927). 1934'te de yapının devamı ziyarete açılır. Ayrıca Ayasofya 1934 tarihinde müzeye dönüştürülür. 1935'te de ziyarete açılır (Keleş, (e-dergi.atauni.edu.tr/ataunisosbil/article/view/102000000: Erişim 01-01-2015).Atatürk Ankara'da bir Hitit müzesi kurulsun istemektedir. 1928'de Etnografya Müzesi açılırken, Dolmabahçe Sarayı Veliaht Dairesi de 30 Eylül 1937'de İstanbul Resim ve Heykel Müzesi'ne dönüştürülür. Bunu diğer illerde açılan, diğer müzeler takip edecektir. Türkiye'de kent müzelerinin kurulması ise, ilk olarak 1990'lı yıllarda İstanbul Büyükşehir Belediyesi'ne bağlı olarak, bugün Yıldız Sarayı bahçesinde yer alan Şehir Müzesi’nin açılmasıyla başlamıştır. Bugünün çağdaş müzelerinde ise artık; sesli yönlendiriciler, sunumlar, dia gösterileri, rehberler eşliğinde gezinti ve atölye çalışmaları mevcuttur. Simülasyonlar ve sanal müzecilik de unutulmamalıdır. Günümüzde, Kültür ve Turizm Bakanlığı'na bağlı 189 müze bulunduğu bilinmektedir. Bakanlık denetiminde de, 155 adet özel müzenin varlığı tespit edilmiştir(Köse, 2010, s. 25; Yücel, 1999, s.67-78 ; Altunbaş, Özdemir, 2012, s. 6, 12). Türkiye'de modern dönemde; özellikle de 1980'lerden itibaren sanat koleksiyonculuğu daha bir önem kazanmaktadır. 2000'li yıllarda bir çok yerde sergi, sergileme olanağı mevcut hale gelmiştir. Ayrıca ülkemizde, Kültür ve Turizm Bakanlığı'na bağlı müze denetimlerinde binlerce kayıtlı koleksiyoner bulunduğu da bilinenler arasındadir.

Koleksiyonerler edindikleri, taşınır kültür varlıklarını envarterlemek ve bağlı oldukları müzelere bildirmek zorundadırlar. Ayrıca Kültür ve Turizm Bakanlı̆̆ı'na bildirmek şartıyla kendi aralarında alım-satım da yapabilmektedirler. Nihayetinde; bilinçli, bilgi sahibi olan ve kültür varlıklarına zarar vermeyen- tahribata uğratmayan ve korumanın önemini bilen kişilerden koleksiyoner olmaları özendirilmeli ve gelişimleri teşvik edilmeli ve bilim dünyasına kazanımları sağlanmalıdır (Başgelen, 2007, s. 5-6).

\section{Sonuç, Bulgular}

İlk etapta ihtiyaçlarını gidermek zorunda olan insanoğlu, bununla birlikte kimi zaman dinsel güdülerini doyurmak gayesiyle de araştırmış, keşfetmiş ve toplayıcılığa başlamıştır. Bu toplama ve keşfetme arzusu insanları, müzecilik ve müze kavramlarına götürmüş ve sanat koleksiyonculuğu da ortaya çıkmıştır. "müzeler", kültür varlıklarının toplandıkları, sergilendiği kuruluşlardır. Eski eserlerin korunması ve değerlendirilmesiyle birlikte gelecek kuşaklara aktarılması ise, en önemli görevleri arasındadır. Tüm bunların akabinde de başta arkeoloji biliminin gelişmesine ön ayak olur. Tüm dünyada olduğu gibi Türkiye'de daha doğrusu Osmanlılarda da, bu biriktirme ve saklama olguları, müzeciliğe giden yolu açar. Osmanlı'nın zengin kütüphaneleri ile başlatabileceğimiz saklama, 
biriktirme ve toplama isteği, Aya İrini’den “Müze-i Hümayun”a ilk müzelerin meydana gelmesine sebep olur. Bu arada devreye önemli arkeologlar girer.

Osmanlı'da, arkeoloji ve eski eserlerden anlayan çok sayıda elemana ihtiyaç duyulması ile de, Müze-i Hümayun'a bağl1 "İzeddiniye-Asar-1 Atika Okulu-Müze-i Hümayun Mektebi veya Arkeoloji Mektebi” isimleri verilen okul kurulacaktır. Böylelikle, müzeye personel yetiştirilebilecektir. Ancak tüm yapılan çalışmalara rağmen bu okul açılamaz. Fakat böyle bir girişimin varlığı bile, Osmanlının eski eserlere verdiği önemi nt şekilde gözler önüne sermektedir.

Daha sonraki çalışmalar, Osman Hamdi Bey, kazılar nihayetinde İstanbul'da bir arkeoloji müzesi açılmasıyla nihayetlenir. Koleksiyonculuk anlayışı da hızlıca devam eder. Elbet, koleksiyonculuğun gelişimi ve devamı olmuştur olmasına ancak bu durum, sanat eserlerinin korunması kavram ve bilinciyle uyuşmakta mıdır, tartışılır...

Bugünkü anlamda müzeler, müzecilik ve koleksiyonerlik, insanların kültür ve sanat alanına yenilik getirmeyi ve ilgi çekmeyi amaçlamaktadır. Unutulmaması gerekli olan en temel nokta ise nesnelerin, gelecek kuşaklara saklanması, korunması ve koruma bilincinin oluşturulması olmalıdır.

\section{Kaynakça}

Altunbaş, A., Özdemir, Ç. (2012). Çăgdaş Müzecilik Anlayışı ve Ülkemizde Müzeler. Ankara:Kültür ve Turizm Bakanlığ1.

Akçura, N. (1972). Türkiye ve Eski Eserler. Mimarlık/Forum, (8), s.39-42.

Başgelen, N. (2006). Müze-i Hümayun'dan Günümüze İstanbul Arkeoloji Müzeleri. Arkeoloji,(14), 114-121.

Başgelen, N. (2007). Türkiye'de Koleksiyonculuk ve Arkeolojik Mirasın Korunması. İstanbul:Arkeoloji ve Sanat yayınlar1.

Başgelen, N. (2010).Ölümünün 100. Yıldönümünde Osman Hamdi Bey, Yaptı̆̆ı Kazılar-Bulduğu Eserler. İstanbul:Arkeoloji ve Sanat yayınları.

Çal, H. Türkiye'de Cumhuriyet Devri Taşınmaz Eski Eser Tahribatı ve Sebepleri.

Erişim: dergiler.ankara.edu.tr/dergiler/26/1249/14313.pdf, s.353-378. 10.10.2019 tarihinde erişilmiştir.

Dede, E. (2012). Türkiye'de Modern Sanatın Gelişiminin Sanat Müzelerine Etkisi. (Yayınlanmamış Yüksek Lisans Tezi). İstanbul Üniversitesi / Sosyal Bilimler Enstitüsü. İstanbul.

Eldem, E. (2010). Osman Hamdi Bey Sözlüğ̈̈, İstanbul: TC. Kültür ve Turizm Bakanlığı Yayınları.

Eldem, E. (2011). Huzurlu bir ilgisizlikten sıkıntılı bir kaygıya: Osmanlı'nın Gözünde Eski Eserler, 1799-1869.Z. Bahrani, Z. Çelik, E. Eldem (Ed.), Geçmişe Hücum-Osmanlı Imparatorluğu'nda Arkeolojinin Öyküsü (1753-1914)içinde (s. 281-329). İstanbul: Salt-Garanti Kültür.

Gerçek, F. (1999). Türk Müzeciliği, Ankara: TC. Kültür Bakanlığı TTK Basımevi.

Keleş, V. Modern Müzecilik ve Türk Müzeciliği. Atatürk Üniversitesi Sosyal Bilimler Enstitüsü Dergisi,2, 1-17:(edergi.atauni.edu.tr/ataunisosbil/article/view/102000000 : Erişim 01-01-2015).

Kocabaş, R. Müzecilik Hareketi ve İlk Müze Okulu'nun Açılışı. Belgelerle Türk Tarihi Dergisi,(21), 77,78.

Köse, E. (2010). Uygulamalar Işı̆̆ında Türkiye'de Kent Müzeciliği Kavramının Değerlendirilmesi.(Kültür ve Turizm Bakanlığı-Kültür Varlıkları ve Müzeler Genel Müdürlüğü Yayınlanmamış Uzmanlık Tezi) . Ankara.

Kuruloğlu, F. (2010). Osmanlı Devleti'nde Müzecilik. Tarih Okulu, (VI), 45-61.

Nazır, B. (2010). Osmanlı Devleti’nde Müzeciliğin Doğusu ve DersaadetNumunehane-i Osmani. HistoryStudies, 2(1), 98-113.

Özsezgin, K. (2014). Çağdaş Sanatımızda Son Osmanlı Osmanlı Hamdi, İstanbul: Kaynak Yayınları.

Serbestoğlu, İ.,Açık, T. (2013). Osmanlı Devleti’nde Modern Bir Okul Projesi.Akademik Bakış, 6 (12) , 157-172.

Shaw, W.M.K. (2004). Osmanlı Müzeciliği-Müzeler, Arkeoloji ve Tarihin Görselleştirilmesi. Esin Soğancılar (Çev). İstanbul: İletişim yayını. 
Shaw, W. M. K. (2011). Anıt Mezardan Müzeye: Eski Eserlerin Osmanlı Modernitesi için Dirilişi. Z. Bahrani, Z. Çelik, E. Eldem (Ed.), Geçmişe Hücum-Osmanlı Imparatorluğu'nda Arkeolojinin Öyküsü (17531914)içinde(s. 423-441). İstanbul: Salt-Garanti Kültür.

Şahin, G. Avrupalıların Osmanlı Ülkesindeki Eski Eserlerle İlgi İzlenimleri ve Osmanlı Müzeciliği. Erişim: dergiler.ankara.edu.tr/dergiler/18/831/10505.pdf, (s.101-125) 10.10.2019 tarihinde erişilmiştir.

Türkseven, H. (2010). Osmanlı Devleti’nde Eski Eser Politikası ve Müze-i Hümayun'un Kuruluşu.(Yayınlanmamış Yüksek Lisans Tezi).Çanakkale Onsekiz Mart Üniversitesi/ Sosyal Bilimler Enstitüsü.Çanakkale .

Yaraş, A. (1994). Anadolu'daki Illk Koleksiyonculuk ve Müzecilik Faaliyetleri. (II. Müzecilik SemineriBildiriler19-23 Eylül 1994, Askeri Müze ve Kültür Sitesi Komutanlığı). İstanbul.19-21.

Yücel, E. (1999).Türkiye'de Müzecilik, İstanbul: Arkeoloji ve Sanat Yayınları.

\section{Extended Abstract}

Among the basic companents which are pioneering the advancement of archeolog science, people's collection curisioty from past to present and the importance of the concepts such as developing collections are quite big. In the process of time, collections were showed to public and these collections were opened to public. In this way, the concepts of the museum museology were born. The first steps were taken for the museums with the collection of the collections. "Museums" are the institutions where cultural properties were collected and exhibited. Museums are places that are communed with the city and they reflect the things that belong to the city. The goal of archeology is to resurrect, but the goal of the museum is to give new life.

Humanity saved food and clothing to satisfy their needs in foraging. They also collected and saved defensive items. In the process of time, they saved and collected precious jewels and items. The savings of the people who adopted a sedentary life probably have formed the most primitive first museum instances of our present day. As it is well known, interest in Works of art increased with the renaissance. In that period of time the firts foundations of future European museums were laid. In 1471, Rome Capitol collection turned into "Capitolino Museum" and in 1506, The Vatican sculpture collection was established in Vatican house. It is mentioned that the first public musem was established in 1683 in England. According to some people, "Ashmoleon museum" in Oxford University is accepted as the first museum. "Charleson museum" in 1773 is accepted as the first public museum in USA. Except for "English museum" "Louvre Museum" in France and "American museum" in 1785 in Philodelphia and "Prado museum" in 1819 in Madrid and "St Petersburg" (Leningrad -Ermitaj museum) are known as museums examples.

It is probable to say about protomuseological concept in Ottoman. This concept coverrs the spoils of war or gathering equipments. As it is well known, while the Hagia Sophia was being built, many stones were provided from the old temples. These Stones were used on the walls of the church. In a similar way, it is mentioned that the Hellenic scultures and pieces were used on the walls of Ankara Castle and Istanbul Rumelian fortress. If this situation is considered as the assessment and display of significant pieces in the Ottoman territories, beginning dates of collection and museum consciousness can also be specified. In fact, most people lead away the history of the Ottoman museology till Anatolian Seljuk. The arcitectural pieces, sculpteres and reliefs belonging to the old period were settle down on Alaaddin hill fortification walls of Konya. Thus, exposure and collection or promuseology were made. In the period of the third Ahmed, "Cebehane-i Amire" was restored and its name was turned into "Darü'l Esliha". In this place, now, precious items are also showed/displayed. So, according to some people, "Darü'l Esliha" is also Pioneer of formal museums. In time, Aya Irini took over this task of hiding. In 1869, Works of art collected in Aya Irini were opened to visit with the name of "Muze-i Humayun".

After some time, because of expectations, the personnels who understand archeology and old artifacts were needed. In this context, it was decided to establis school named as "Izzediniye- Asar-1 Atika school-Muse-i Humayun school" or archeology school attached to "Muze-i Humayun".

Despite all correspondes, the school couldn't opened. According to some people, because the Schedule wasn't well prepared, according to some, because the entrance requirements weren't provited or the students and theatchers weren't avaible. According to some, because of the 93 war, the school couldn't opened. The subsequent Works, Mr. Osman Hamdi's Works and excavations ended with the opening of an archeology museum in Istanbul. The understanding of collecting also contionues fast. Certainly, the collecting continued and developed but does this circumstance match with the awareness protection of artistic works? 
In today's context, Museums, museology and collecting aim to innovate and attract attention. The most important thing is that yhe objects must be protected and the objects must be safed for future generetions and this awareness of protection must be created to future generations. 